\title{
Perlindungan Data Konsumen Transaksi Online Melalui Penerapan Advance Data Protection System
}

\author{
Wahyu Beny Mukti Setiyawan ${ }^{1}$, Hafid Zakariya ${ }^{2}$, Delia Wahtikasari ${ }^{3}$ \\ ${ }^{1,2}$ Fakultas Hukum Universitas Islam Batik Surakarta \\ ${ }^{3}$ Universitas Sebelas Maret Surakarta \\ Correspondence email: muktibeny@gmail.com
}

\begin{abstract}
Abstrak. Konsep negara hukum kesejahteraan menjadi landasan kedudukan dan fungsi pemerintah (bestuurfunctie) dalam negara-negara modern. Penerapan hukum yang ditaati dan diikuti akan menciptakan ketertiban dan memaksimalkan potensi masyarakat. Selanjutnya sesuai dengan tujuan negara yang termaktub dalam alinea keempat pembukaan UUD NRI Tahun 1945 bahwa salah satu tujuan negara adalah untuk melindungi segenap bangsa Indonesia dan untuk memajukan kesejahteraan umum. Dengan dibentuknya tujuan negara tersebut dalam alinea keempat UUD NRI Tahun 1945 menjadi jawaban bahwa sesungguhnya Indonesia telah berusaha untuk mewujudkan welfare state. Kunci pokok dalam negara kesejahteraan adalah mengenai jaminan kesejahteraan rakyat yang diberikan oleh Negara.Pada dasarnya pengaturan menyangkut hak privasi atas data pribadi merupakan manifestasi pengakuan dan perlindungan atas hak-hak dasar manusia. Oleh karena itu, penyusunan Rancangan Undang-Undang Perlindungan Data pribadi memiliki landasan filosofis yang kuat dan dapat di pertanggung jawabkan. Putusan Mahkamah Konstitusi Nomor 006/PUU-I/2003 semakin mempertegas bahwa pengaturan Perlindungan Data Pribadi harus dalam bentuk Undang-Undang. Dalam Putusan Mahkamah Konstitusi tersebut antara lain disebutkan bahwa ketentuan yang menyangkut HAM, harus dalam bentuk Undang-Undang.Sebagai wujud negara hadir untuk melindungi sekaligus mensejahterakan rakyatnya, pemerintah sebagai pemegang kekuasaan tertinggi sekaligus yang menjalankan pemerintahan wajib melakukan usaha-usaha yang di rasa dibutuhkan. Salah satu cara yang dapat dilakukan pemerintah untuk menjawab dan meminimalisir masalah-masalah yang dihadapi adalah dengan menerapkan Advance Data Protection System sebagai suatu wujud perlindungan.
\end{abstract}

Kata Kunci: Konsumen, Transaksi Online, Advance Data Protection System

\begin{abstract}
The concept of a welfare state is the basis for the position and function of government (bestuurfunctie) in modern countries. The application of the law that is obeyed and followed will lead to law and order which maximize the potential of the community. Furthermore, in accordance with the objectives of the state set out in the fourth paragraph of the opening of the 1945 Constitution of the Republic of Indonesia that one of the objectives of the state is to protect the entire Indonesian nation and to advance the general welfare. By the establishment of the country's goals in the fourth paragraph of the 1945 Constitution of the Republic of Indonesia, the answer is that in fact Indonesia has tried to create a welfare state. The main key in the welfare state is regarding the guarantee of people's welfare given by the State. Basically, the regulation concerning the right to privacy of personal data is a manifestation of the recognition and protection of basic human rights. Therefore, the drafting of the Personal Data Protection Bill has a strong philosophical foundation and can be accounted for. Decision of the Constitutional Court Number 006 / PUU-I / 2003 further emphasized that the regulation of Personal Data Protection must be in the form of a law. In the Constitutional Court Decision, among others, it was stated that the provisions concerning human rights must be in the form of laws. As a form of the state present to protect as well as the welfare of its people, the government as the highest authority as well as those who run the government is obliged to carry out efforts that are felt needed. One way that the government can do to answer and minimize the problems faced is by implementing the Advance Data Protection System as a form of protection.
\end{abstract}

\section{Keyword: Consumer, online transaction, Advance Data Protection System}

\section{PENDAHULUAN}

Indonesia merupakan negara hukum, hal tersebut termaktub dalam Pasal 1 Ayat 3 Undang-Undang Dasar Negara Republik Indonesia Tahun 1945 (UUD NRI Tahun 1945) yang menyatakan bahwa "Negara Indonesia adalah negara hukum". Negara hukum atau rechtsstaat dan the rule of law merupakan istilah yang meskipun kelihatan sederhana, namun mengandung muatan sejarah pemikiran yang relatif panjang. ${ }^{1}$ Latar belakang timbulnya pemikiran negara hukum itu merupakan reaksi terhadap kesewenangan-wenangan di masa lampau. ${ }^{2}$ Cita negara hukum untuk pertama kalinya dikemukakan oleh Plato dan kemudian pemikiran tersebut dipertegas oleh Aristoteles. ${ }^{3}$ Plato memiliki konsep bahwa "penyelenggaraan negara yang baik didasarkan pada pengaturan (hukum) yang baik yang

\footnotetext{
${ }^{1}$ Ricardo Gosalbo-Bono, 2014,"The Significance of the Rule of Law and Its Implications for the European Union and The United States," University of Pittsburgh Law Review Vol. 72, No.2 Hlm.232.

${ }^{2}$ CST Kansil, 2002, Pengantar Ilmu Hukum Dan Tata Hukum Indonesia, Jakarta : Balai Pustaka, Hlm.3.

${ }_{3}$ Ake Frandberg, 2014, "From Rechtsstaat to Universal Law-State. An Essay in Philosophical Jurisprudence", London : Springer, Hlm. 103.
} 
Wahyu Beny Mukti Setiyawan et al, Perlindungan Data Konsumen Transaksi Online Melalui Penerapan Advance Data Protection System

disebut dengan istilah "nomoi". Pengertian negara hukum menurut Aristoteles dikaitkan dengan arti dan perumusan yang masih melekat kepada "Polis".4

Dalam polis segala urusan negara dilakukan dengan musyawarah (ecclesia), dimana seluruh warga negaranya ikut serta ambil bagian dalam urusan penyelenggaraan negara. ${ }^{5}$ Arti negara hukum itu sendiri pada hakikatnya berakar dari konsep dan Teori Kedaulatan Hukum yang pada prinsipnya menyatakan bahwa kekuasaan tertinggi di dalam suatu negara adalah hukum. Oleh sebab itu, seluruh alat perlengkapan negara apapun namanya termasuk warga negara harus tunduk dan patuh serta menjungjung tinggi hukum tanpa terkecuali. ${ }^{6}$ Terdapat dua macam negara hukum, yaitu negara hukum formil atau negara hukum klasik dan negara hukum dalam arti materiil atau negara hukum yang bersifat modern. ${ }^{7}$ Dalam arti formil tugas negara adalah melaksanakan peraturan perundang-undangan untuk melaksanakan ketertiban atau lebih dikenal sebagai negara penjaga malam (nachtwackerstaats).

Sementara dalam artian materiil tugas negara tidak hanya sebatas menjaga ketertiban saja, melainkan juga kehadiran negara adalah untuk mencapai kesejahteraan rakyat untuk mencapai keadilan (welfarestate). Fungsi negara dalam arti materiil menjadikan yang utama bagi sebuah negara adalah bertindak sebagai pelayan bagi masyarakat (public service) dalam rangka meningkatkan kesejahteraan masyarakat tersebut. ${ }^{8}$ Konsep welfarestate menjadi landasan kedudukan dan fungsi pemerintah (bestuurfunctie) dalam negara-negara modern saat ini. Penerapan hukum yang ditaati dan diikuti akan menciptakan ketertiban dan memaksimalkan potensi masyarakat untuk mencapai kesejahteraannya. Selanjutnya sesuai dengan tujuan negara yang termaktub dalam alinea keempat pembukaan UUD NRI Tahun 1945 bahwa salah satu tujuan Negara adalah untuk melindungi segenap bangsa Indonesia dan untuk memajukan kesejahteraan umum. Dengan dibentuknya tujuan negara tersebut dalam alinea keempat UUD NRI Tahun 1945 menjadi jawaban bahwa sesungguhnya Indonesia telah berusaha untuk mewujudkan welfarestate. Pada hakikatnya negara kesejahteraan dapat digambarkan keberadaannya sebagai pengaruh dari hasrat manusia.

Demi menunjang kesejahteraan masyarakat Indonesia, maka Indonesia membutuhkan adanya teknologi sebagai faktor pendorong untuk mencapai sebuah kesejahteraan. Teknologi sebagai pemegang peranan yang sangat penting saat ini dalam kehidupan masyarakat, yang mana dapat merubah sikap dan perilaku manusia. ${ }^{9}$ Dewasa ini, peluang dan tantangan sangat bervariasi sebagai akibat dari penggunaan teknologi yang menyentuh berbagai kalangan masyarakat, sebut saja pemanfaatan teknologi dalam perdagangan (e-commerce), transportasi, penyampaian informasi, industri, pariwisata, pemerintahan, dan industri keuangan. Menandai penggunaan teknologi komunikasi dan informasi yang begitu mudah dan masif dalam masyarakat ini dikenallah istilah Revolusi industri ke-4. ${ }^{10}$

Semua kegiatan manusia saat ini sangat terikat dengan kebutuhan teknologi komunikasi dan informasi yang terus berkembang dan berinovasi tanpa jeda. Teknologi komputer yang semakin canggih itu memenuhi kebutuhan ruang artificial intelligence (ai), e-commerce, big data, shared economic, termasuk sistem robotik yang terus berkembang dalam memenuhi kebutuhan manusia. ${ }^{11}$ Teknologi komunikasi dan informasi semakin maju dan canggih hingga mempengaruhi berbagai bidang kehidupan setiap negara salah satunya adalah bidang ekonomi. Tidak hanya mempengaruhi bidang ekonomi secara makro tetapi juga mempengaruhi bidang ekonomi secara mikro termasuk bidang industrial seperti yang digunakan untuk membuat Industrial Internet of Things (IIoT), robotika atau aplikasi Big Data. Big data pada dasarnya merupakan database yang mencakup data besar dan kompleks, sehingga harus menggunakan perangkat modern untuk pemrosesannya. ${ }^{12}$

Perkembangan teknologi Big Data sendiri memberikan banyak keuntungan apabila dapat diolah dan dipergunakan dengan baik seperti dengan adanya analisis data kebiasaan konsumen, perusahaan atau pelaku bisnis yang ada di Indonesia untuk mengetahui dan meningkatkan peluang usahanya serta jenis atau barang apa saja yang diperlukan konsumen untuk mereka tawarkan. ${ }^{13}$ Menurut Bank Indonesia (BI) Agus Martowardojo meyakini bahwa dengan pemanfaatan big data yang tepat dapat mendongkrak pertumbuhan ekonomi hingga 7\%. Terlebih lagi saat ini

\footnotetext{
${ }^{4}$ Aristotle, 1998, "Politics", Indianapolis : Hackett Publishing Company, Hlm.65.

${ }^{5}$ Ibid. Hlm. 40.

${ }^{6}$ B. Hestu Cipto Handoyo, 2009,“Menuju Konsolidasi Sistem Demokrasi”, Jakarta : Universitas Atma Jaya, Hlm. 17.

${ }^{7}$ Uthrecht, 1962, "Pengantar Hukum Administrasi Negara Indonesia", Jakarta : Ichtiar, Hlm. 9.

${ }^{8}$ B. Hestu Cipto Handoyo, Op.cit, Hlm.20.

${ }^{9}$ F.H. Edy Nugroho,2017, “Kemampuan Hukum Dalam Mengatasi Perkembangan Teknologi”, Jakarta: Makalah. Hlm. 7

${ }^{10}$ Hendra Suwardana, "Revolusi Industri 4.0 Berbasis Revolusi Mental”, Jurnal Jati Unik, Vol. 1, No. 2, Hlm. 5.

${ }^{11}$ Sri Ayu Astuti, 2018, "Impact of Industrial Revolution 4.0 and the Utilization of Digital Media Technology towards Siber Community Behavior (Dampak Revolusi Industri 4.0 Dan Kemanfaatan Teknologi Media Digital Terhadap Perilaku Buruk Masyarakat Siber)", Vol. 2, No. 2, Hlm. 487.

12 Http://www.teknologi-bigdata.com/2013/02/big-data-dan-rahasia-kejayaan-google.html, diakses pada 18/03/2020,
} Pukul 21.19 wib.

${ }^{13} \mathrm{Http}$ ///binus.ac.id/malang/2019/06/peran-big-data-dalam-bisnis/, diakses pada 18/03/2020, Pukul 21.31 wib. 
era keterbukaan informasi sangat pesat seiring hadirnya sosial media. ${ }^{14}$ Walaupun memberikan banyak keuntungan, namun analisis Big Data sendiri masih bertentangan dengan aturan yang tertuang dalam pasal Undang-Undang Informasi dan Transaksi Elektronik No. 19 Tahun 2016 (UU ITE) jika digunakan dengan tidak semestinya oleh pihak yang tidak bertanggung jawab.

Dampak yang ditimbulkan dari adanya permasalahan penyalahgunaan aturan tersebut banyak yang merugikan masyarakat. Contohnya pada tahun 2016 telah terjadi permasalahan berkenaan dengan data pribadi dimana terdapat kebocoran data pengguna Gojek dan Grab, yang mana data sensitif milik pelanggan dan pengemudi, seperti nama, alamat, nomor telepon, koordinat, dan tujuan, masih bisa diakses dari API endpoint yang dimiliki kedua penyedia transportasi online tersebut. ${ }^{15}$ Menurut pendangan pengamat teknologi yaitu Donny Budi Utoyo mengatakan bahwa kejadian tersebut sudah gawat dan tidak bisa ditoleransi lagi bukan hanya data pribadi pengguna yang bocor tetapi juga perilaku mereka. ${ }^{16}$ Selain itu terdapat penyalahgunaan terhadap data pribadi dalam bentuk lain yang disebut Pesan Berbasis Lokasi. Seperti penyebutannya yang berbasis lokasi, penyalahgunaan ini dengan cara mengakses lokasi individu, sehingga individu dapat secara otomatis mendapat short message servise (SMS) berisi iklan. ${ }^{17}$ Dalam hal ini para pengguna khawatir bahwa informasi-informasi tersebut dapat disalahgunakan untuk kepentingan dan pemasaran produk-produk tertentu yang tidak dikehendakinya ataupun untuk kepentingan lainnya. ${ }^{18}$

Melihat dua fakta sosiologis tersebut, sudah seharusnya perlindungan terhadap data pribadi pengguna merupakan prioritas tertinggi yang harus dilindungi oleh pemerintah agar penggunaan data pribadi yang digunakan oleh penyedia layanan e-commerce tidak merugikan masyarakat. Hal ini memunculkan perhatian bahwa perlu adanya sebuah aturan terkait hak privasi terhadap data pribadi. Data pribadi merupakan perwujudan dari hak-hak dasar manusia yang diatur dalam Undang-undang dan Pancasila, sehingga pembuatan aturan mengenai hak privasi terhadap data pribadi penting untuk dirumuskan. ${ }^{19}$

Asas fungsi sosial menyebutkan bahwa terdapat jaminan kepentingan atau ketertiban umum, sehingga penggunaan data pribadi oleh pihak pemerintah maupun swasta harus memperhatikan hak-hak masyarakat dan perlu dilakukan pembatasan demi terciptanya sebuah tatanan perdaban manusia yang adil dan mampu menghormati dan menghargai hak privasi terhadap data pribadi. ${ }^{20}$ Berdasarkan pada uraian di atas, sangat menarik apabila diamati dinamika antara adanya Perlindungan Data Pribadi dan praktik analisis pengumpulan Big Data. Penulis meyakini bahwa setiap regulasi serta lembaga yang dibentuk untuk mengawasi perlindungan data telah melalui pertimbangan yang matang. Tetapi apakah pertimbangan tersebut telah memenuhi asas perlindungan dan kesejahteraan yang menjadi tujuan Negara.

\section{HASIL DAN PEMBAHASAN \\ Penerapan Advanced Data Protection System dalam Meminimalkan Risiko Penyalahgunaan Data Pribadi Konsumen}

Beberapa tahun belakangan, masyarakat Indonesia dari kalangan artis hingga masyarakat biasa marak mengalami penipuan yang menggunakan situs jual beli daring. ${ }^{21}$ Data-data pribadi berkenaan dengan kependudukan dan demografis di Indonesia seperti Nomor Induk Kependudukan (NIK), Kartu Tanda Penduduk Elektronik (EKTP),dan Kartu Keluarga (KK) sangat penting untuk dilindungi agar tidak mudah disalagunakan oleh beberapa pihak seperti penjualan data, data profiling, tujuan pemasaran, penelitian, bahkan termasuk pemantauan (spionase) dan kejahatan serta pelanggaran lainnya. Selain itu, ketiadaan prinsip etika pada aktivitas penawaran langsung secara daring untuk menawarkan produk-produk asuransi dan pinjaman tanpa agunan dengan melakukan perpindahan data nasabah juga menjadi keresahan masyarakat Indonesia. Hal tersebut juga dapat mendorong pengunaan data pribadi oleh pihak ketiga untuk tindak kriminal dalam jaringan pasar gelap, maupun digunakan untuk keperluan non-legal. ${ }^{22}$

\footnotetext{
${ }^{14}$ Https://tekno.kompas.com/read/2016/01/20/16031307/Kebocoran.GoJek.Memuncak.Rute.Sehar ihari.Penggu.Bisa.Dilacakna>, diakses pada 18/03/2020, Pukul 21.40 wib.

${ }^{15}$ Reska K. Nistanto, "Kebocoran Go-Jek Memuncak, Rute Sehari-hari Pengguna Bisa Dilacak", https://tekno.kompas.com/read/2016/01/20/16031307/Kebocoran.GoJek.Memuncak.Rute.Sehari hari.Pengguna.Bisa.Dil acak, diakses pada 18/03/2020, Pukul 21.58 wib.

16 Ibid.

${ }^{17}$ Naskah Akademik, 2015, "Perlindungan Data Pribadi”, Hlm. 126-127.

${ }^{18}$ Edmon Makarim, 2005, “Pengantar Hukum Telematika”, Jakarta : PT Raja Grafindo Persada, Hlm. 184.

${ }^{19}$ Selengkapnya dapat dilihat Pasal 3 Undang-Undang No. 39 Tahun 1999 Tentang Hak asasi Manusia.

${ }^{20}$ Ibid.

21 Https://www.merdeka.com/teknologi/tingkat-kepercayaan-pada-e-commerce-masih-rendah.html>, diakses pada
} 18/03/2020, Pukul 22.05 wib.

$2^{2}$ Lia Sautunnida, 2018, “Urgensi Undang-Undang Perlindungan Data Pribadi di Indonesia”,

Kanun Jurnal Ilmu Hukum, Vol. 20, No. 2, Hlm.369-384. 
Pentingnya analisis data pada tercapainya penguasaan pasar dan sebagai landasan arah pengembangan bisnis di masa depan, menjadikan data berhubungan erat dengan bisnis pada era teknologi saat ini. Kepemilikan data lengkap beserta segala analisisnya merupakan kemampuan yang wajib dimiliki sebuah perusahaan untuk menentukan arah kebijakan dalam mendorong perusahaan berkembang pesat. ${ }^{23}$

Dalam perkembangannya, penggunaan Big Data tersebut digunakan untuk menunjang kehidupan manusia. Data sudah sepantasnya digunakan dalam hal-hal bijak. ${ }^{24}$ Karena jika data raksasa diolah secara tepat justru dapat membantu dan menghasilkan berbagai solusi untuk kesinambungan warga dunia. Namun, diperlukan suatu teknologi khusus untuk mengolah data yang jumlahnya sangat besar tersebut. Untuk mendapatkan nilai dari big data diperlukan metodologi khusus yang berkaitan dengan analisis data dan kemampuan dalam pengolahan. Di tangan para ilmuwan, data ini bisa memiliki nilai ekonomis yang tinggi karena dapat memberikan berbagai informasi dan pengetahuan. ${ }^{25}$ Belakangan, sektor publik juga sudah mulai memanfaatkan big data. Pada sektor publik, big data dapat dimanfaatkan untuk misalnya mendeteksi dini kanker dan penyakit lainnya berdasarkan pola dari data historis pasien sebelumnya.

Kemudahan dalam melakukan deteksi dini pada penyakit tidak kemudian membenarkan pemanfaatan big data itu sendiri. Perlindungan data pribadi tetap menjadi hal penting yang harus dilakukan untuk saat ini. Dalam kaitannya dengan perlindungan data pribadi, menurut Wahyudi Djafar dan Asep Komarudin menyebutkan adanya konsep privasi, yakni sebuah ide untuk mengedepankan integritas dan nilai diri. ${ }^{26}$ Melindungi data diri memiliki kaitan erat dengan konsep privasi yang telah dikemukakan tersebut, dimana hak privasi memungkinkan seseorang untuk menentukan pemegang informasi dan bagaimana itu digunakan. ${ }^{27}$ Adanya rumusan tentang konsep hak privasi memungkinkan rumusan hak perlindungan terhadap data pribadi yang saat ini mulai disalahgunakan. ${ }^{28}$

\section{Penerapan Advanced Data Protection System dalam Meminimalkan Risiko Perlindungan Data Pribadi Konsumen}

Advanced Data Protection System merupakan suatu sistem yang dapat digunakan untuk melindungi data pribadi konsumen. Sistem ini akan memberikan perlindungan dengan menekankan beberapa prinsip. Dalam melaksanakan prinsip ini, mengacu kepada beberapa prinsip perlindungan data pribadi yang ada di Uni Eropa, Hongkong, dan Singapura.

\section{Pelaksanaan Perlindungan Data Pribadi di Uni Eropa}

Data pribadi adalah data yang dimiliki oleh seorang individu yang disebut dengan pemilik data, dimana data pribadi ini dapat digunakan untuk melakukan identifikasi terhadap individu tersebut karena memuat informasi yang berkaitan erat dengan dirinya. ${ }^{29}$ General Data Protection Regulation (GDPR) merupakan rangkaian peraturan yang bertujuan untuk memberikan perlindungan terhadap data pribadi serta untuk memperkuat konsistensi penerapan perlindungan tersebut di seluruh Uni Eropa. GDPR ini mewajibkan pebisnis, pemerintah, maupun organisasiorganisasi lain untuk mengungkapkan lebih banyak hal kepada pengguna mengenai praktik data mereka, dan mengatur bagaimana mereka mengumpulkan, memproses, dan menyimpan data mereka. ${ }^{30}$ The European Union Charter of Fundamental Right memberikan pengakuan terhadap perlindungan data pribadi dan privasi sebagai sebuah hak besar di Uni Eropa, dimana UE kemudian melegalkan perlindungan terhadap data diri pada tahun 2016 silam yang bertujuan untuk menciptakan perlindungan data diri pada masa sekarang dimana teknologi memiliki peranan yang sangat penting di segala lini. ${ }^{31}$

Peraturan perlindungan data diri yang dirumuskan dalam perjanjian tersebut, menerapkan beberapa prinsip, guna memberikan perlindungan bagi indvidu dan data yang mungkin saja diberikan ke perusahaan. Prinsip-prinsip tersebut adalah sebagai berikut:

\footnotetext{
${ }^{23}$ Agung Pujianto,et.al, September 2018, "Pemanfaatan Big Data Dan Perlindungan Privasi

Konsumen Di Era Ekonomi Digital”, Vol. 15, No. 2, Hlm.127 - 137.

${ }^{24}$ Hidayah Dhini, 2018, “Gerai Info Edisi 72 Tahun VII”, hlm. 8.

25 Ibid, Hlm. 9.

26 Wahyudi Djafar dan Asep Komarudin, "Perlindungan Hak Atas Privasi di Internet-Beberapa Penjelasan Kunci”,

${ }^{27}$ Lord Ester dan D, Pannick (ed.) dalam ibid, hlm. 6.

${ }^{28}$ Human Rights Committee General Comment No. 16, 1998, "on the right to respect of privacy, family, home and correspondence, and protection of honour and reputation (art. 17) seperti yang dikutip dalam Privacy International Report", hlm.

${ }^{29}$ European Union Agency for Fundamental Rights and Council of Europe, 2014, Handbook on European Data

30 <https://www.hrw.org/id/news/2018/06/06/320234> diakses pada 18/03/2020, Pukul 23.05 wib

31 Sinta Dewi Rosadi, 2018, "Perlindungan Privasi Dan Data Pribadi Dalam Era Ekonomi Digital Di Indonesia",Vol.
} Elsam, Jakarta, 2014, hlm. 12. $1-2$. Protection Law, Belgium, hlm.36. 4,No. 1, hlm. 105. 
Pertama, Perlu adanya persetujuan dari individu sebelum perusahaan memutuskan untuk mengupulkan dan menggunakan data dari individu tersebut. Pengajuan persetujuan harus jelas, dan menggunakan format yang dapat dimengerti, kemudahan dalam mengakses, dan ditulis dengan bahasa yang jelas dan sederhana.

Kedua, adanya pemberlakuan perlindungan khusus pada informasi yang dinilai sangat pribadi, seperti identifikasi online dan lokasi. Hal ini memungkinkan cookie, identifikasi perangkat, dan alamat internet mendapat perlindungan setara dengan data pribadi.

Ketiga, adanya keharusan untuk melaporkan cara data individu digunakan, dibagikan, maupun disimpan. Hal ini tetap berlaku untuk data yang diperoleh dari perusahaan makelar data atau perusahaan media sosial.

Keempat, siapapun dapat meminta perusahaan membagikan informasi mengenai data pribadi apa yang dipegang oleh perusahaan tersebut secara gratis, lalu meminta data tersebut agar dihapus.

Kelima, seseorang dapat mengunduh data pribadi mereka dan memindahkan ke kompetitor melalui hak atas portabilitas data yang baru. Misalnya, semua orang semestinya bisa mengambil data mereka dari satu jaringan media sosial atau lembaga keuangan dalam format yang memungkinkan mereka untuk berpindah layanan dengan mudah.

Keenam, perusahaan didorong untuk mengembangkan mekanisme perlindungan privasi kedalam sistem mereka. Dalam peraturan ini, mereka yang memproses data harus menerapkan langkah-langkah keamanan teknis dan organisasional. ${ }^{32}$

\section{Pelaksanaan Perlindungan Data Pribadi di Hongkong Personal Data Privacy Ordinance of 1995 (PDPO)}

Hongkong merupakan peraturan perlindungan data pribadi pertama di Asia. Prinsip perlindungan data pribadi ini mengandung prinsip sebagai berikut:

Pertama, batasan pengumpulan data pribadi. Dalam hal ini pengumpulan data dilakukan secara sah untuk tujuan yang secara langsung berhubungan dengan fungsi dari pengumpulan data tersebut. Data yang dikumpulkan harus cukup, namun pengumpulan data pribadi tidak boleh melebihi tujuan pengumpulan data tersebut. ${ }^{33}$

Kedua, penggunaan dan pengungkapan data pribadi. Prinsip ini membatasi pengungkapan data pribadi hanya untuk tujuan awal pengumpulan data tersebut, dan apabila disetujui oleh pemilik data.

Ketiga, kewajiban kualitas data dan pemberian saran kepada pihak ketiga. Prinsip ini mewajibkan seluruh langkah yang mungkin diambil harus menjamin akurasi data tersebut dan untuk menghapus dan tidak menggunakan data yang tidak akurat. Data yang tidak akurat didefinisikan sebagai data yang tidak benar, menyesatkan, tidak lengkap, dan tidak mutakhir. ${ }^{34}$ Dalam hal ini penggunaan data yang tidak akurat tidak dengan sendirinya menjadi suatu pelanggaran apabila telah ditempuh langkah untuk menghindari ketidakakuratan suatu data.

Keempat, penghapusan dan pemusnahan data pribadi. Dalam hal ini, data pribadi tidak boleh disimpan lebih lama dari jangka waktu yang telah ditentukan dalam pemenuhan tujuan.

Kelima, kewajiban keamanan data. Pengelola data pribadi wajib melakukan setiap langkah yang memungkinkan untuk melindungi data pribadi dari akses yang tidak disengaja, atau pemrosesan, penghapusan, penghilangan, dan penggunaan tidak sah.

Keenam, keterbukaan mengenai praktik-praktik. Data user harus mengambil langkah-langkah untuk menjamin bahwa setiap orang dapat menentukan kebijakan dan praktik mengenai data pribadi, jenis data pribadi yang disimpan data user, dan tujuan utama penggunaanya. Ketiadaan publikasi kebijakan privasi di perusahaan-perusahaan ataupun organisasi merupakan pelanggaran dari prinsip keterbukaan mengenai praktik perlindungan data pribadi.

\section{Pelaksanaan Perlindungan Data Pribadi di Singapura}

Data pribadi di Singapura dilindungi dalam The Personal Data Protection Act No. 26 of 2012 Singapore (PDPA 2012 Singapura). Dalam peraturan ini, memuat beberapa prinsip yaitu: ${ }^{35}$

Pertama, prinsip consent. Suatu organisasi atau perusahaan yang ingin mendapatkan, menggunakan, atau membuka data pribadi seseorang harus mendapatkan persetujuan dari pemilik data pribadi tersebut.

Kedua, prinsip purpose. Suatu organisasi atau perusahaan yang ingin mendapatkan, menggunakan, atau membuka data pribadi seseorang harus memberikan informasi yang lengkap terkait tujuan penggunaan data pribadi orang tersebut secara lengkap

Ketiga, prinsip reasonableness. Suatu organisasi atau perusahaan yang ingin mendapatkan, menggunakan, atau membuka data pribadi, ataupun menginformasikan data pribadi milik seseorang harus melakukannya dengan tujuan yang pantas dan beralasan.

\footnotetext{
${ }^{32}$ Selengkapnya data lihat dalam Peraturan Perlindungan Data Pribadi Uni Eropa GDPR

${ }^{33}$ Greeneaf Graham, 2014, “Asian Data Privacy-Trade and Human Right Perspective”, Oxford University Press, hlm.80.

${ }^{34}$ Selengkapnya dapat dilihat dalam Personal Data Privacy Ordinance (PDPO) Hongkong Seksi 2 ayat 1.

${ }^{35}$ Selengkapnya dapat dilihat dalam The Personal Data Protection Act No. 26 of 2012 Singapore
} 
Perkembangan pengaturan data pribadi secara umum akan menempatkan Indonesia sejajar dengan negaranegara dengan tingkat perekonomian yang maju, yang telah menerapkan hukum mengenai perlindungan data pribadi. Hal ini akan lebih mendorong dan memperkuat posisi Indonesia sebagai pusat bisnis terpercaya, yang merupakan suatu strategi kunci dalam ekonomi nasional Indonesia.

Bagi kepentingan konsumen, kebutuhan akan perlindungan data pribadi konsumen terutama pada era Revolusi Industri 4.0 dimana data pribadi menjadi sangat berharga bagi kepentingan bisnis, sehingga menimbulkan kekhawatiran bahwa data pribadi konsumen dijual atau digunakan tanpa persetujuan mereka, sebagaimana contoh pelanggaran yang telah diuraikan sebelumnya. Untuk itu, terlihat kebutuhan akan suatu perundang-undangan mengenai perlindungan data pribadi yang bersifat khusus untuk memastikan bahwa data pribadi konsumen dilindungi dengan baik.

Bagi perkembangan ekonomi, perlindungan data pribadi yang bersifat khusus akan memperkuat posisi Indonesia sebagai pusat bisnis dan investasi terpercaya dan menciptakan lingkungan yang kondusif untuk pertumbuhan manajemen data global, pengolahan dan pemanfaatan analisis Big Data untuk berkembang di Indonesia.

Advance Data Protection System tersebut nantinya akan diterapkan dengan mengadopsi beberapa prinsipprinsip yang telah diterapkan oleh tiga negara diatas yang kemudian digabungkan menjadi suatu prinsip yang baru yang dapat diterapkan di negara Indonesia, yang mana prinsip tersebut terdiri dari:

Pertama, perlunya persetujuan konsumen bagi perusahaan atau organisasi yang bermaksud menggunakan data mereka.

Kedua, perlunya ada pembatasan dalam menggunakan data pribadi, dimana penggunaannya hendaknya berdasarkan pada tujuan yang jelas berdasarkan fungsi dari data pribadi.

Ketiga, dalam menggunakan data pribadi, harus diadakan pembedaan antara data sensitif dan non-sensitif.

Keempat, dalam penggunaan data pribadi yang dilakukan oleh perusahaan atau organisasi, maka konsumen berhak untuk meminta penghapusan data pribadi kepada perusahaan atau organisasi yang menggunakan data pribadi tersebut.

Advance Data Protection ini dibuat dengan harapan agar dapat mendukung pelaksanaan RUU Perlindungan Data Pribadi nantinya, sehingga apabila RUU dan juga Advance Data Protection System ini berjalan seiringan dan saling melengkapi dalam penerapannya, maka terwujudlah salah satu tujuan negara Indonesia yakni mewujudkan kesejahteraan. Karena, apabila perlindungan data pribadi sudah terpenuhi dengan baik dan dapat memberi rasa aman bagi masyarakat sebagai konsumen dalam melakukan transaksi secara elektronik, juga untuk memberikan keuntungan bagi para pengusaha e-commerce di Indonesia yang nantinya akan membawa dampak bagi percepatan perekonomian Indonesia melalui perkembangan e-commerce, maka nantinya perkembangan transaksi elektronik semakin cepat dan membawa dampak pada tumbuhnya percepatan perekonomian Indonesia. Sehingga terwujud pulalah cita hukum Indonesia rakyat Indonesia yang berkeadilan.

\section{SIMPULAN}

Berbagai aturan untuk melindungi dan mengatur tentang penggunaan, perlindungan serta keamanan data pribadi konsumen dalam bertransaksi secara elektronik pada kenyataanya telah dibuat dan diterapkan oleh Kominfo maupun OJK. Aturan tersebut terdapat pada Peraturan Jasa Keuangan No.1/POJK.07/2013 tentang Perlindungan Konsumen Sektor Jasa Keuangan dan Undang-Undang No. 19 Tahun 2016 tentang Informasi dan Transaksi Elektronik, Undang-Undang No. 8 Tahun 1999 tentang Perlindungan Konsumen serta beberapa peraturan lain yang tersebar dibeberapa peraturan perundang-undangan lainnya. Penguatan daya saing Indonesia dapat dilakukan dengan melindungi data pribadi yang bersifat khusus dengan perlindungan yang memadai, untuk melindungi sekaligus mensejahterakan rakyatnya, pemerintah sebagai pemegang kekuasaan tertinggi sekaligus yang menjalankan pemerintahan wajib melakukan usaha-usaha yang dirasa dibutuhkan. Salah satu cara yang dapat dilakukan pemerintah untuk menjawab dan meminimalisir masalah-masalah yang dihadapi adalah dengan menerapkan Advance Data Protection System sebagai suatu wujud perlindungan yang merupakan hasil dan konsep ideal yang didapatkan dengan membandingkan beberapa pelaksanaan sistem perlindungan dan aturan yang telah diterapkan di beberapa negara. Dengan adanya perlindungan dan rasa aman terhadap data pribadi maka akan menciptakan kepercayaan terhadap perusahaan-perusahaan e-commerce yang akan melakukan kegiatan usaha, maka akan memberikan percepatan terhadap pertumbuhan ekonomi Indonesia.

\section{DAFTAR PUSTAKA}

\section{Buku}

Ake Frandberg, 2014, From Rechtsstaat to Universal Law-State. An Essay in Philosophical Jurisprudence, London : Springer

Aristotle, 1998, Politics, Indianapolis : Hackett Publishing Company 
Wahyu Beny Mukti Setiyawan et al, Perlindungan Data Konsumen Transaksi Online Melalui Penerapan Advance Data Protection System

B. Hestu Cipto Handoyo, 2009, Menuju Konsolidasi Sistem Demokrasi, Jakarta : Universitas Atma Jaya CST Kansil, 2002, Pengantar Ilmu Hukum Dan Tata Hukum Indonesia, Jakarta : Balai Pustaka

Edmon Makarim, 2005, Pengantar Hukum Telematika, Jakarta : PT Raja Grafindo Persada

F.H. Edy Nugroho, 2017, Kemampuan Hukum Dalam Mengatasi Perkembangan Teknologi, Jakarta : Makalah

Greeneaf Graham, 2014, Asian Data Privacy-Trade and Human Right Perspective, Oxford University Press

European Union Agency for Fundamental Rights and Council of Europe, 2014, Handbook on European Data Protection Law, Belgium

Uthrecht, 1962, Pengantar Hukum Administrasi Negara Indonesia, Jakarta : Ichtiar

Wahyudi Djafar dan Asep Komarudin, 2014, Perlindungan Hak Atas Privasi di Internet-Beberapa Penjelasan Kunci, Elsam, Jakarta

\section{Peraturan perundang-undangan}

Peraturan Perlindungan Data Pribadi Uni Eropa GDPR

Undang-Undang Nomor 39 Tahun 1999 Tentang Hak asasi Manusia

\section{Jurnal}

Hendra Suwardana, "Revolusi Industri 4.0 Berbasis Revolusi Mental”, Jurnal Jati Unik, Vol. 1, No. 2

Lia Sautunnida , 2018, "Urgensi Undang-Undang Perlindungan Data Pribadi di Indonesia”, Kanun Jurnal Ilmu Hukum, Vol. 20, No. 2

Hidayah Dhini, 2018, "Gerai Info Edisi 72 Tahun VII

Human Rights Committee General Comment No. 16, 1998, on the right to respect of privacy, family, home and correspondence, and protection of honour and reputation.

Ricardo Gosalbo-Bono, 2014,"The Significance of the Rule of Law and Its Implications for the European Union and The United States," University of Pittsburgh Law Review Vol. 72, No.2

Sinta Dewi Rosadi, 2018, Perlindungan Privasi Dan Data Pribadi Dalam Era Ekonomi Digital Di Indonesia",Vol. 4, No. 1

Sri Ayu Astuti, 2018, "Impact of Industrial Revolution 4.0 and the Utilization of Digital Media Technology towards Siber Community Behavior (Dampak Revolusi Industri 4.0 Dan Kemanfaatan Teknologi Media Digital Terhadap Perilaku Buruk Masyarakat Siber)”, Vol. 2, No. 2

\section{Internet}

Http://binus.ac.id/malang/2019/06/peran-big-data-dalam-bisnis/

Https://www.merdeka.com/teknologi/tingkat-kepercayaan-pada-e-commerce-masih-rendah.html

Http://www.teknologi-bigdata.com/2013/02/big-data-dan-rahasia-kejayaan-google.html

https://tekno.kompas.com/read/2016/01/20/16031307/Kebocoran.GoJek.Memuncak.Rute.Sehari hari.Pengguna.Bisa.Dil acak

Https://tekno.kompas.com/read/2016/01/20/16031307/Kebocoran.GoJek.Memuncak.Rute.Sehar ihari.Penggu.Bisa.Dilacakna

ttps://www.hrw.org/id/news/2018/06/06/320234 